Zeszyty Naukowe Szkoły Głównej Gospodarstwa Wiejskiego w Warszawie

Problemy Rolnictwa Światowego tom 18 (XXXIII), zeszyt 4, 2018: 426-436

DOI: 10.22630/PRS.2018.18.4.131

Wioleta Sobczak $^{1}$, Rafal Zbyrowski ${ }^{2}$

${ }^{1}$ Szkoła Główna Gospodarstwa Wiejskiego w Warszawie,

${ }^{2}$ Uniwersytet Warszawski

\title{
Integracja przestrzenna rynków hurtowych - zastosowanie dla rynku fasoli szparagowej
}

\section{Spatial Integration of Wholesale Markets - Application for the Green Bean Market}

\begin{abstract}
Synopsis. Celem opracowania była ocena poziomu integracji przestrzennej rynków hurtowych owoców i warzyw na przykładzie fasoli szparagowej. W pracy podjęto problem mechanizmu powiązań cenowych i transmisji cen pomiędzy rynkami hurtowymi. Do opracowania wykorzystano dzienne notowania cen analizowanego gatunku na pięciu rynkach hurtowych w Polsce. Do opracowania danych posłużyły metody ekonometryczne tj. wybrane modele ekonometrii dynamicznej. Wskazano, że znaczenie poszczególnych rynków hurtowych w kreowaniu cen zależy m.in. od wielkości rynku oraz jego lokalizacji.
\end{abstract}

Slowa kluczowe: transmisja cen, integracja przestrzenna, model VAR, przyczynowość w sensie Grangera, funkcja odpowiedzi na impuls

\begin{abstract}
The aim of the study was to assess the level of spatial integration of wholesale fruit and vegetable markets in Poland based on the example of green bean, with respect to the results of research on a global scale. The paper discusses the problem of the price mechanism and transmission between the wholesale markets. The daily price quotations of the analyzed species on five wholesale markets in Poland were used for the study. Econometric methods, that is selected models of dynamic econometrics, were used to develop the data
\end{abstract}

Key words: price transmission, spatial integration, VAR model, Granger causality, impulse response function

JEL Classification: Q13, C32

\section{Wprowadzenie}

Analiza relacji przestrzennych cen ma na celu wyjaśnienie przestrzennych aspektów funkcjonowania i interakcji rynków (Serra i in., 2006). Integracja przestrzenna rynków odnosi się do sytuacji, w której ceny towaru na przestrzennie oddzielonych rynkach zmieniają się równolegle, zaś sygnały i informacje przekazywane są płynnie pomiędzy nimi. Stąd też integracja rynków może być oceniana w kategoriach relacji między cenami na przestrzennie oddzielonych rynkach (Ghos, 2000; Rembeza i Chotkowski, 2006). Powiązanie cenowe pomiędzy rynkami rolnymi na tym samym poziomie łańcucha

\footnotetext{
${ }^{1}$ dr, Wydział Nauk Ekonomicznych, Katedra Polityki Europejskiej i Marketingu, ul. Nowoursynowska 166, 02-787 Warszawa, e-mail: wioleta_sobczak@sggw.pl; https://orcid.org/0000-0003-3812-3877

${ }^{2}$ dr, Wydział Zarządzania, Samodzielny Zakład Badań Operacyjnych Zarządzania, ul. Szturmowa 1/3, 02-678 Warszawa, e-mail: rzbyrowski@wz.uw.edu.pl; https://orcid.org/0000-0001-8499-8899
} 
dystrybucji określa się poziomą transmisją cen. Jest ona związana z przenoszeniem impulsów cenowych tych samych produktów w różnych lokalizacjach. Zjawisko to definiowane jest jako przestrzenna transmisja cen (ang. spatial price transmission) lub integracja przestrzenna rynków (ang. spatial market integration) [Stachowiak 2013]. Według Goodwina i Schroedera (1991) o integracji dwóch rynków można mówić w sytuacji, gdy zmiana cen na jednym rynku znajduje pełne odzwierciedlenie w zmianie poziomu cen na innym rynku. Z uwagi na fakt, iż poziom cen w gospodarce kształtowany jest na podstawie relacji podaży i popytu, poziom integracji rynku można zdefiniować również jako miarę, w jakim stopniu fluktuacja tych dwóch zmiennych na danym rynku jest przekazywana na pozostałe powiązane ze sobą rynki (Goletti, Ahmed, Farid, 1995; Negassa, Meyers, Gabre-Maldhin, 2004).

Analiza integracji przestrzennej rynków jest bardzo często wykorzystywana w ocenie ogólnej sprawności systemu rynkowego (Faminow, Benson, 1990). Integracja przestrzennie oddalonych rynków ma szczególne znaczenie w rolnictwie, czyli w sektorze gospodarki, w którym produkty cechują się niską trwałością, zaś miejsce ich konsumpcji znajduje się często w znacznych odległościach od miejsca produkcji, co potencjalnie przyczynia się do wzrostu kosztów produkcji i dystrybucji (Sexton, Kling, Carman, 1991). Brak integracji rynków prowadzi do zaburzeń w przesyłaniu sygnałów cenowych pomiędzy nimi, co skutkuje nieefektywną alokacją zasobów i błędnymi decyzjami odnośnie do miejsca sprzedaży produktów.

W warunkach liberalizacji integracja rynków nabrała przyspieszenia. Jednostki przestrzenne takie jak m.in. państwa podlegają wpływom sąsiadujących z nimi jednostek. Są one tym samym zależne od zachodzących w nich procesów ekonomicznych, politycznych oraz społecznych. Ceny między lokalizacjami mogą być zróżnicowane. Wynika to między innymi $\mathrm{z}$ restrykcji handlowych, kosztów transportu a w ujęciu międzynarodowym z wahań kursu walutowego oraz niejednolitych stawek podatkowych.

Rynek produktów ogrodniczych jest powiązany $\mathrm{z}$ innymi rynkami branżowymi. Pomimo, że jest elementem rynku rolniczego to wyróżnia się wysokim poziomem sezonowości, znacznym udziałem małych, niezorganizowanych podmiotów, a także szerokim asortymentem produktów o zróżnicowanym poziomie jakości. Ponadto zarówno warzywa, jak również owoce charakteryzują się znacznym zróżnicowaniem pod względem trwałości, tolerancji na transport, a także niejednorodności w zakresie jakości i zasad przygotowania towaru do sprzedaży, co powoduje destabilizację tego rynku (Gołębiewski, Sobczak, 2017). Destabilizacja ta bardzo często wiąże się z występowaniem istotnych fluktuacji w poziomie cen zarówno w przekroju czasowym jak również przestrzennym, a tym samym przyczynia się do występowania asymetrii $\mathrm{w}$ transmisji cen i braku zintegrowania przestrzennego. Należy przy tym zauważyć, że pomiar integracji rynków hurtowych może stać się jednym z narzędzi służących do zrozumienia ich funkcjonowania, a tym samym ułatwić producentom podejmowanie decyzji dotyczących miejsca sprzedaży swoich produktów.

Ze względu na proces globalizacji oraz istotne znaczenie międzynarodowej wymiany handlowej produktami ogrodniczymi poznanie poziomu integracji rynków w zakresie kształtowania się cen w poszczególnych państwach jest aspektem bardzo istotnym dla prowadzonej polityki handlowej. Niewielka liczba aktualnych opracowań w tym zakresie zarówno na poziomie krajowym, jak i światowym wskazuje na konieczność podjęcia dalszych analiz dotyczących integracji przestrzennej rynków. Ponadto stosunkowo niewiele analiz zostało przeprowadzonych $\mathrm{w}$ odniesieniu do owoców i warzyw, zarówno w 
literaturze krajowej jak również światowej. Analiza przestrzennej integracji rynków w zakresie tych gatunków prowadzona była między innymi w Wielkiej Brytanii, Francji, Indonezji, USA, Meksyku, Kenii. Ze względu na brak opracowań dotyczących integracji przestrzennej rynków hurtowych w sektorze ogrodniczym istotnym jest podjęcie tego tematu, co uzupełni krajową lukę w tym obszarze.

Celem opracowania była ocena poziomu integracji przestrzennej rynków hurtowych owoców i warzyw w Polsce w przypadku gatunków sezonowych na przykładzie fasoli szparagowej.

\section{Dane i metody}

Na potrzeby badań wybrano pięć rynków hurtowych, tj. Warszawski RolnoSpożywczy Rynek Hurtowy S.A. w Broniszach, Wielkopolską Gildię Rolno-Ogrodniczą S.A. w Poznaniu, Rolno Spożywczy Rynek Hurtowy Giełda Kaliska Sp. z o.o., RolnoSpożywczy Rynek Hurtowy S.A. w Radomiu oraz Sandomierski Ogrodniczy Rynek Hurtowy S.A, Wyboru celowego rynków dokonano, kierując się takimi czynnikami, jak wielkość, zasięg i charakter rynku. W wyborze uwzględniono również dostępność i porównywalność danych w zakresie dziennych notowań cen. Zakres czasowy analizowanych cen obejmował lata 2011-2016, łączna liczba obserwacji wyniosła 2380. Baza dziennych notowań cen zawierała nieliczne braki danych, jednak przed przeprowadzeniem badania empirycznego dane zostały zbilansowane. W przypadku doboru gatunku kierowano się okresem, przez jaki gatunek ten, jako produkt krajowy, dostępny jest w formie świeżej na rynku (gatunek sezonowy) oraz dostępnością i porównywalnością danych w zakresie notowań cen. Notowane ceny były cenami deklarowanymi przez producentów jako ceny ofertowe. Dane zostały pozyskane bezpośrednio z rynków hurtowych oraz Stowarzyszenia Polskie Rynki Hurtowe.

Do określenia występowania współzależności cen fasoli szparagowej na rynkach hurtowych posłużyły metody ekonometryczne. W celu doboru odpowiedniej metodyki badań w pierwszej kolejności dokonano oceny właściwości szeregów czasowych w zakresie ich stacjonarności przy wykorzystaniu rozszerzonego testu Dickeya-Fullera (ADF, Augmented Dickey-Fuller test). Test ADF wykorzystuje model regresji pomocniczej o postaci:

$$
\Delta y_{t}=\delta y_{t-1}+\sum_{i=1}^{k} \gamma_{i} \Delta y_{t-1}+\varepsilon_{t}
$$

gdzie: $\delta$ i $\gamma$-parametry szacowane metodą najmniejszych kwadratów, $k$-liczba opóźnień, $\Delta \mathrm{y}_{\mathrm{t}-1}$ - wartość szeregu pierwszych różnic badanego zjawiska w okresie t-1, $\varepsilon_{\mathrm{t}}-$ składnik losowy (Maddala, 2008). Hipoteza zerowa testu mówi, że szereg $y_{t}$ jest niestacjonarny z powodu wystąpienia pierwiastka jednostkowego, natomiast hipoteza alternatywna wskazuje, że szereg jest stacjonarny.

Zmienność cen analizowana jest na wielu płaszczyznach, w większości przypadków są to zmiany poziomów cen w określonym przedziale czasowym na różnych rynkach. $W$ tym celu stosowane są dynamiczne modele ekonometryczne (Borkowski, Krawiec, 2009). W celu określenia zmienności poziomów cen we wskazanym przedziale czasowym na różnych rynkach zastosowano dynamiczny model ekonometryczny Vector Autoregression Model - 
VAR, który nie posiada podziału na zmienne endogeniczne oraz egzogeniczne. Wszystkie zmienne $\mathrm{w}$ tym modelu są zmiennymi objaśnianymi, zaś ich opóźnienia zmiennymi objaśniającymi. Model ten jest modelem wielorównaniowym o strukturze autoregresyjnej. Model VAR jest alternatywą dla klasycznego modelu wielorównaniowego o równaniach współzależnych. Postać modelu VAR można zapisać jako:

$$
X_{t}=A_{0} D_{t}+\sum_{i=1}^{k} A_{k} x_{t-k}+e_{t}
$$

gdzie: $X_{\mathrm{t}}=\left[\begin{array}{lll}x_{t l} & \ldots & x_{t k}\end{array}\right]^{T}-$ wektor obserwacji na bieżących wartościach wszystkich zmiennych objaśniających, $D_{t}-$ wektor egzogenicznych składników równań, takich jak wyraz wolny, zmiana czasowa, niestochastyczne regresory, opóźnione wartości zmiennych egzogenicznych, $A_{0}$ - macierz parametrów przy zmiennych wektora $D_{t}$ (nie zawiera zerowych elementów), $A_{i}$ - macierz parametrów przy opóźnionych zmiennych wektora $x_{t}$ (nie zawiera zerowych elementów), $k$ - rząd modelu, określający maksymalną długość opóźnienia, $e_{t}=\left[\begin{array}{lll}e_{l t} & \ldots & e_{k t}\end{array}\right]^{T}$ - wektory stacjonarnych zakłóceń losowych (wektory reszt równań modelu) (Sims, 1980; Kusideł, 2000).

Do przeprowadzenia analizy zależności przyczynowo-skutkowych pomiędzy analizowanymi zmiennymi posłużono się przyczynowością w sensie Grangera, która określa czy jedna zmienna jest przyczyną innej zmiennej. Zgodnie z powyższym zmienna $x$ jest przyczyną w sensie Grangera zmiennej $y$ w przypadku, gdy wartości zmiennej $y$ mogą być dokładniej prognozowane poprzez uwzględnienie przeszłej wartości zmiennej $x$ niż bez uwzględniania tych wartości. Przyczynowość w sensie Grangera opiera się na poniższym układzie równań:

$$
\begin{aligned}
& Y_{t}=\beta_{0}+\sum_{j=1}^{m} \beta_{j} Y_{t-j}+\sum_{k=l}^{n} \beta_{k} X_{t-k}+u_{t} \\
& X_{t}=\beta_{0}+\sum_{j=1}^{m} \beta_{j} X_{t-j}+\sum_{k=l}^{n} \beta_{k} Y_{t-k}+u_{t}
\end{aligned}
$$

gdzie: $Y_{\mathrm{t}}$ - wartości zmiennej $\mathrm{Y}, X_{\mathrm{t}}$ - wartości zmiennej $\mathrm{X}, \beta$ - parametry strukturalne modelu, $u_{t}-$ składnik losowy modelu (Granger, 1969). Hipoteza zerowa $\mathrm{w}$ teście przyczynowości w sensie Grangera mówi, że wszystkie współczynniki $\beta_{k}$ są równe zero, co oznacza brak przyczynowości, natomiast hipoteza alternatywna zakłada występowanie przyczynowości.

W celu szczegółowego opisu przebiegu zależności pomiędzy cenami na badanych rynkach hurtowych posłużono się funkcją odpowiedzi na impulsy - IRF (ang. Impulse Response Function). Funkcja IRF przyjmuje postać średniej ruchomej uwzględniającej oddziaływania zakłóceń losowych (Kusideł, 2000):

$$
X_{t}=\sum_{i=1}^{\infty} \Phi_{i} \xi_{t-1}
$$


gdzie:

$B$ - macierz parametrów stojących przy nieopóźnionych wartościach wektora $X_{t}$, $\Phi_{\mathrm{i}}-$ odpowiedź wyróżnionej zmiennej wektora $X_{t}$ na impuls ze strony innej zmiennej.

\section{Wyniki badań}

Analizując poziom cen fasoli szparagowej na wybranych rynkach hurtowych w Polsce zauważono, że w latach 2011 - 2016 charakteryzowały się one dużą zmiennościa, co obrazuje rysunek 1. Przy czym największe wahania w ich poziomie wystapiły na Rolno Spożywczym Rynku Hurtowym Giełda Kaliska Sp. z o.o. oraz Sandomierskim Ogrodniczym Rynku Hurtowym S.A. Na podstawie przeprowadzonych analiz można wnioskować, że najbardziej stabilnym rynkiem hurtowym w przypadku fasoli szparagowej w badanym okresie był Warszawski Rolno-Spożywczy Rynek Hurtowy S.A. w Broniszach.

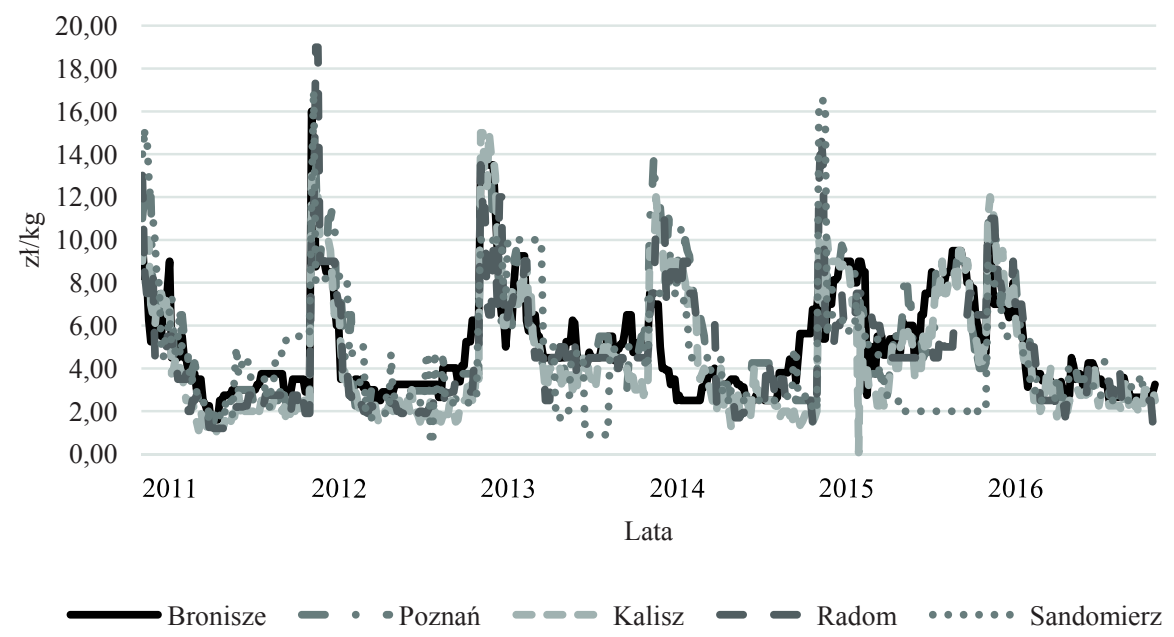

Rys. 1. Poziom cen fasoli szparagowej na analizowanych rynkach hurtowych

Fig. 1. The price level of green beans on wholesale markets analyzed

Źródło: obliczenia i opracowanie własne przy wykorzystaniu programu EViews.

Badanie współzależności szeregów czasowych wymaga określenia ich stacjonarności. Poziom zintegrowania badanych dziennych notowań cen fasoli szparagowej zbadano za pomoca rozszerzonego testu Dickey'a-Fullera (ADF). Zgodnie z założeniami testu ADF hipoteza zerowa stanowi, że badane szeregi czasowe są niestacjonarne. Stąd jeżeli obliczona wartość testu ADF jest mniejsza niż wartość krytyczna hipoteza zerowa zostaje odrzucona na rzecz hipotezy alternatywnej (stacjonarności zmiennej). W przeprowadzonym teście stacjonarności ADF właściwa liczba opóźnień $k$ została dobrana na podstawie kryteriów informacyjnych Schwarz'a. Dla badanych notowań cen nie zaobserwowano zmian wartości średniej arytmetycznej w czasie, stąd w równaniach poszczególnych testów nie uwzględniono trendu deterministycznego, a jedynie wartość stałą. Na wykresach cen fasoli szparagowej w czasie zauważyć można krótkookresowe fluktuacje, które mogą mieć 
związek z występowaniem zjawiska sezonowości. W tym przypadku zmienność ta nie miała wpływu na ostateczne wyniki testu stacjonarności - testy wykonano zarówno dla danych pierwotnych jak i poddanych odsezonowaniu. Na etapie modelowania VAR powtórnie podjęto próby uwzględnienia sezonowości jako składowej wektora deterministycznego, jednak nie przyniosło to oczekiwanych rezultatów. Wyniki testu dla analizowanych szeregów czasowych zaprezentowane w tabeli 1, które wskazują na stacjonarność wszystkich badanych zmiennych.

Tabela 1. Wyniki testów stacjonarności szeregów czasowych badanych cen fasoli szparagowej

Table 1. Results of stationary tests of time series of the examined prices of green beans

\begin{tabular}{l|cccc}
\hline \multirow{2}{*}{$\begin{array}{c}\text { Wyszczególnienie } \\
\text { Rynki hurtowe }\end{array}$} & Statystyka testu ADF & $p$-value $=0,01$ & $p$-value $=0,05$ & $p$-value $=0,1$ \\
\hline Bronisze & $-5,114$ & $-3,444$ & $-2,867$ & $-2,570$ \\
Poznań & $-4,861$ & $-3,444$ & $-2,867$ & $-2,570$ \\
Kalisz & $-4,759$ & $-3,444$ & $-2,867$ & $-2,570$ \\
Radom & $-5,876$ & $-3,444$ & $-2,867$ & $-2,570$ \\
Sandomierz & $-5,783$ & $-3,444$ & $-2,867$ & $-2,570$ \\
\hline
\end{tabular}

Źródło: obliczenia i opracowanie własne przy wykorzystaniu programu EViews.

Parametry oszacowane w modelu VAR dla poziomów (dane nielogarytmowane), również wskazały na istnienie integracji przestrzennej pomiędzy cenami tego gatunku na wszystkich badanych rynkach hurtowych (tab. 2). Większość parametrów równań dla modelu VAR była istotna statystycznie wskazując, że zmiany cen na poszczególnych rynkach są od siebie uzależnione. Wyniki estymacji parametrów modelu VAR wskazały, że zmiany cen na badanych rynkach były we wszystkich przypadkach istotnych statystycznie dodatnie. Ponadto należy zauważyć, że zmiany cen na danym rynku silniej reagują na jednostkową zmianę ceny odnotowaną na tym samym rynku niż na jednostkowe zmiany cen na innych rynkach. Przy czym powyższe stwierdzenie dotyczy opóźnienia o 1 okres. Dodatkowo przeprowadzone analizy z zastosowaniem opóźnienia większego niż 1 okres nie wykazały zmian w występowaniu relacji cenowej pomiędzy rynkami hurtowymi.

Oszacowany model VAR generuje stacjonarne szeregi składników resztowych, które jednak podlegają autokorelacji do drugiego rządu opóźnienia. Wskazuje na to sprawdzian statystyki testu LM (Test mnożnika Lagrange'a) o wartości 121,5. Ponadto zawarte w Tabeli 2 testy Jarque-Bera dla reszt poszczególnych równań modelu sugerują możliwość występowania w tym przypadku rozkładów nienormalnych. Jest to jednak kwestia dyskusyjna ponieważ badanie zostało przeprowadzone na relatywnie dużym zbiorze danych (2380 obserwacji -dane dzienne w okresie ponad 5 lat). W teście Jarque-Bera dla dużej próby wszelkie odstępstwa od rozkładu normalnego pod względem kurtozy i asymetrii zostają mocno uwypuklone $\mathrm{z}$ powodu obecności trzeciego i czwartego momentu centralnego $\mathrm{w}$ formule testu. 
Tabela 2. Wyniki estymacji parametrów modelu VAR

Table 2. The results of the VAR model parameter estimation

\begin{tabular}{|c|c|c|c|c|c|}
\hline Wyszczególnienie & Bronisz & Poznań & Kalisz & Radom & Sandomierz \\
\hline \multirow[t]{3}{*}{ Bronisz(-1) } & 0.900518 & 0.057547 & 0.149756 & 0.099441 & 0.085976 \\
\hline & $(0.03176)$ & $(0.03432)$ & $(0.03762)$ & $(0.03854)$ & $(0.04025)$ \\
\hline & [28.3496] & {$[1.67660]$} & [3.98061] & [2.58024] & {$[2.13610]$} \\
\hline \multirow[t]{3}{*}{ Poznań(-1) } & -0.054381 & 0.648419 & 0.156601 & 0.137648 & -0.002777 \\
\hline & $(0.04473)$ & $(0.04834)$ & $(0.05298)$ & $(0.05428)$ & $(0.05668)$ \\
\hline & {$[-1.21564]$} & [13.4143] & {$[2.95573]$} & {$[2.53611]$} & {$[-0.04900]$} \\
\hline \multirow[t]{3}{*}{ Kalisz(-1) } & 0.091682 & 0.251250 & 0.681690 & 0.029240 & -0.035124 \\
\hline & $(0.04624)$ & $(0.04996)$ & $(0.05476)$ & $(0.05610)$ & $(0.05859)$ \\
\hline & [1.98281] & {$[5.02868]$} & {$[12.4478]$} & {$[0.52120]$} & {$[-0.59949]$} \\
\hline \multirow[t]{3}{*}{$\operatorname{Radom}(-1)$} & -0.036658 & -0.046871 & -0.013960 & 0.660780 & 0.062951 \\
\hline & $(0.03232)$ & $(0.03493)$ & $(0.03828)$ & $(0.03922)$ & $(0.04096)$ \\
\hline & {$[-1.13413]$} & {$[-1.34198]$} & {$[-0.36467]$} & [16.8494] & [1.53703] \\
\hline \multirow[t]{3}{*}{ Sandomierz(-1) } & -0.024634 & 0.022683 & 0.018687 & 0.020407 & 0.833118 \\
\hline & $(0.02177)$ & $(0.02352)$ & $(0.02578)$ & $(0.02641)$ & $(0.02758)$ \\
\hline & {$[-1.13172]$} & [0.96439] & {$[0.72484]$} & {$[0.77270]$} & [30.2061] \\
\hline \multirow[t]{3}{*}{$\mathrm{C}$} & 0.623208 & 0.478319 & -0.150842 & 0.118884 & 0.184798 \\
\hline & $(0.12140)$ & $(0.13118)$ & $(0.14379)$ & $(0.14730)$ & $(0.15383)$ \\
\hline & [5.13338] & {$[3.64621]$} & {$[-1.04907]$} & {$[0.80711]$} & {$[1.20131]$} \\
\hline R-squared & 0.822495 & 0.851100 & 0.844671 & 0.800910 & 0.802890 \\
\hline Adj. R-squared & 0.820642 & 0.849545 & 0.843050 & 0.798832 & 0.800832 \\
\hline Jarque-Bera: & 93921.45 & 1545.146 & 4031.221 & 5210.244 & 21828.10 \\
\hline LM-Stat: & & & 121.5160 & & \\
\hline
\end{tabular}

Poziom błędu w ( ), T-Studenta [ ], parametry istotne statystycznie - kolor szary (poziom istotności $-\alpha=0,05$ ); C-stała modelu

Źródło: obliczenia i opracowanie własne przy wykorzystaniu programu EViews.

Wyniki testu przyczynowości Grangera w przypadku fasoli szparagowej zamieszczone w tabeli 3 wskazały na wzajemne oddziaływanie cen tylko w przypadku wybranych rynków hurtowych. Radomski i sandomierski rynek hurtowy nie miały wpływu na kształtowanie cen fasoli szparagowej na większości rynków hurtowych, przy czym należy zauważyć, że były one odbiorcą informacji cenowej. Należy jednocześnie powiedzieć, że oddziaływanie na wszystkie badane rynki w latach 2011 - 2016 miały impulsy wynikające ze zmiany cen fasoli szparagowej na Warszawskim Rolno-Spożywczym Rynku Hurtowym S.A. w Broniszach (tab. 3). 
Tabela 3. Wyniki testu przyczynowości Grangera dla fasoli szparagowej

Table 3. Granger causality test results for green beans

\begin{tabular}{|c|c|c|c|c|c|}
\hline Wyszczególnienie & Bronisze & Poznań & Kalisz & Radom & Sandomierz \\
\hline Bronisze & $\mathrm{X}$ & $\begin{array}{c}\rightarrow \\
(7.5 \mathrm{E}-05)\end{array}$ & $\begin{array}{c}\rightarrow \\
(5.0 \mathrm{E}-05)\end{array}$ & $\begin{array}{c}\rightarrow \\
(4.0 \mathrm{E}-08)\end{array}$ & $\begin{array}{c}\rightarrow \\
(0.00178)\end{array}$ \\
\hline Poznań & $\mathrm{X}$ & $\mathrm{X}$ & $\begin{array}{c}\rightarrow \\
0.00118\end{array}$ & $\begin{array}{c}\rightarrow \\
(8.3 \mathrm{E}-10)\end{array}$ & $\begin{array}{c}\rightarrow \\
(0.02900)\end{array}$ \\
\hline Kalisz & $\mathrm{X}$ & $\begin{array}{c}\rightarrow \\
(9.4 \mathrm{E}-10)\end{array}$ & $\mathrm{X}$ & $\begin{array}{c}\rightarrow \\
(8.4 \mathrm{E}-09)\end{array}$ & $\begin{array}{c}\rightarrow \\
(0.02326)\end{array}$ \\
\hline Radom & $\mathrm{X}$ & $\mathrm{X}$ & $\mathrm{X}$ & $\mathrm{X}$ & $\begin{array}{c}\rightarrow \\
(0.00642)\end{array}$ \\
\hline Sandomierz & $\mathrm{X}$ & $\mathrm{X}$ & $\mathrm{X}$ & $\begin{array}{c}\rightarrow \\
(0.02951)\end{array}$ & $\mathrm{X}$ \\
\hline
\end{tabular}

W celu uzyskania szczegółowych informacji o wzajemnych dostosowaniach cen na poszczególnych rynkach posłużono się funkcjami odpowiedzi na impuls (IRF). Kolejność zmiennych uwzględnionych $\mathrm{w}$ badaniu podyktowana była wielkością rynku hurtowego. Zmienne zostały uszeregowane od rynku największego w Broniszach do najmniejszego w Sandomierzu. Kolejność zmiennych jest w tym przypadku o tyle istotna, że wpływa na wyniki badania $\mathrm{i}$ jeśli to możliwe jest ustalana $\mathrm{w}$ oparciu o wiedzę merytoryczną i doświadczenie badacza. Funkcje IRF wyznaczone zostały dzięki wynikom estymacji parametrów modelu VAR dla poziomów (dane nie zostały zlogarytmowane). Rysunek 2 obrazuje wzajemne dostosowania cen pomiędzy analizowanymi rynkami.

Przebieg funkcji IRF potwierdza wzajemne oddziaływanie cen, w przypadku których estymacja modelu VAR wskazała występowanie współzależności w ich kształtowaniu się, wskazując jednocześnie brak reakcji w przypadku wystąienia impulsów cenowych pomiędzy rynkami, w przypadku których parametry modelu VAR nie były istotne statystycznie. Analiza przebiegu funkcji IRF (rysunek 1) ukazuje, że poszczególne funkcje wygasają w perspektywie okresu $10 \mathrm{dni}$, zatem wygenerowane relacje mają tendencję do powracania do stanu równowagi. W większości przypadków już po upływie 7 dni (tzn. tygodnia) od pojawienia się impulsu zauważyć można znaczący powrót do równowagi na danym rynku hurtowym. Jednocześnie warto zwrócić uwagę na stosunkowo silne oddziaływanie największego rynku w Broniszach na poziom notowań cen na pozostałych rynkach hurtowych - pamiętając również że to właśnie Bronisze zostały na pierwszym miejscu uwzględnione w przeprowadzonym badaniu IRF. 
Reakcja rynku hurtowego w Broniszach

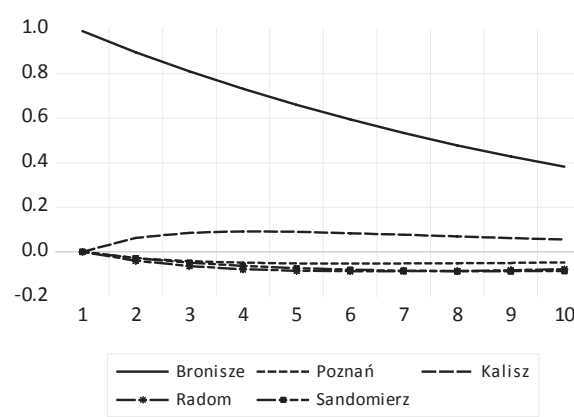

Reakcja rynku hurtowego w Kaliszu

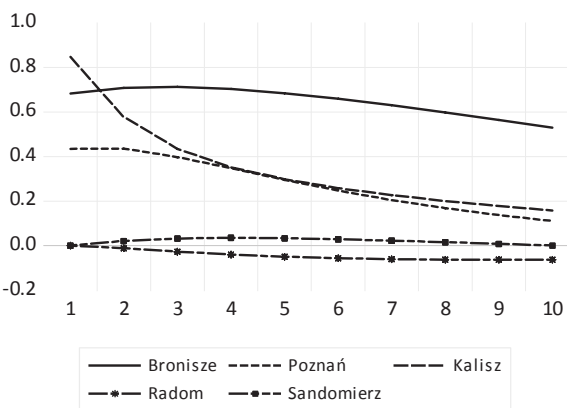

Reakcja rynku hurtowego w Sandmierzu

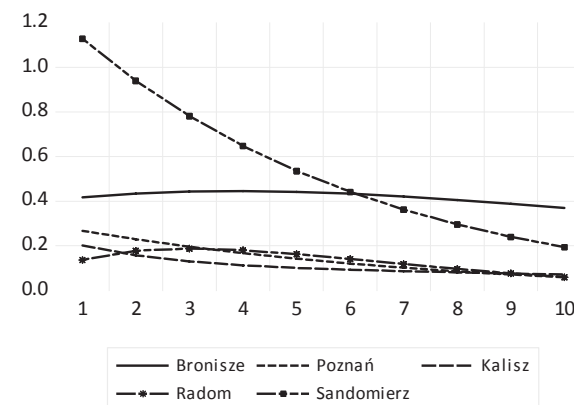

Reakcja rynku hurtowego w Poznaniu

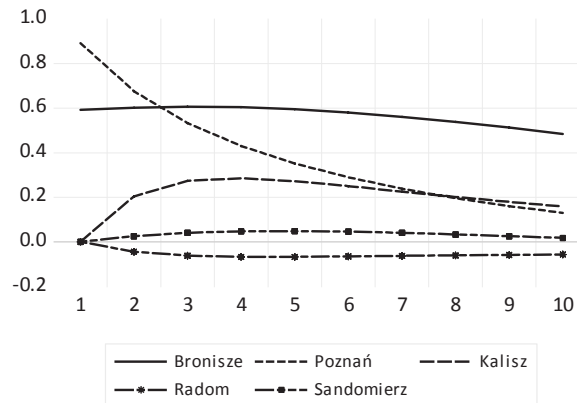

Reakcja rynku hurtowego w Radomiu

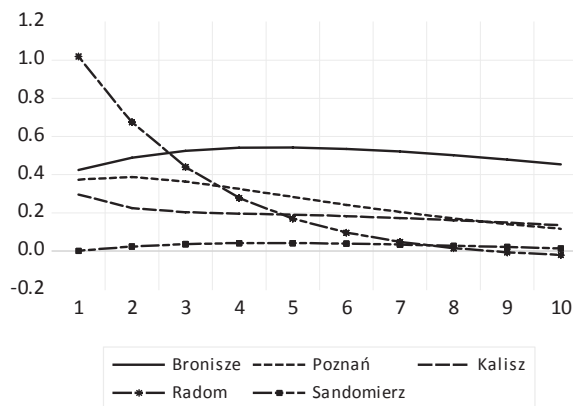

Oś X - dni; Oś Y - cena w zł

Rys. 2. Reakcja poszczególnych rynków na impuls w postaci zmiany cen fasoli szparagowej.

Fig. 2. The reaction of individual markets to the impulse in the form of a change in the price of green beans. Źródło: Obliczenia i opracowanie własne przy wykorzystaniu programu EViews. 


\section{Podsumowanie i dyskusja}

Niniejsze badania zostały przeprowadzone przy zastosowaniu metod ekonometrii dynamicznej do określenia dynamiki dostosowań cenowych w przypadku fasoli szparagowej jako gatunku z kategorii warzyw sezonowych, obecnego na rynku przez krótki czas. Zbadano współzależności między cenami fasoli szparagowej na 5 rynkach hurtowych Polsce wśród których znalazły się Warszawski Rolno-Spożywczy Rynek Hurtowy S.A. w Broniszach, Wielkopolska Gilda Rolno-Ogrodnicza S.A., Rolno-Spożywczy Rynek Hurtowy Giełda Kaliska Sp. z o.o., Rolno-Spożywczy Rynek Hurtowy S.A. w Radomiu oraz Sandomierski Ogrodniczy Rynek Hurtowy S.A. Oszacowane parametry modelu VAR sugerują, że największe znaczenie w kształtowaniu cen na danym rynku hurtowym miał poziom cen $z$ dnia poprzedniego na tym samym rynku. Ponadto wskazano występowanie integracji rynków z Warszawskim Rolno-Spożywczym Rynkiem Hurtowym S.A. w Broniszach

Uzyskane wyniki testu przyczynowości Grangera pokazały, że siła i kierunek wzajemnych relacji cen były zróżnicowane w poszczególnych przypadkach. Podobne wyniki uzyskał Mauyo i współautorzy (2007), którzy dokonali pomiaru stopnia integracji rynków regionalnych w przypadku fasoli w Kenii i Ugandzie, wykazując, że pomiędzy analizowanymi rynkami występuje silne powiązanie cen.

Poziom integracji rynków warzyw sezonowych w literaturze został również przeanalizowany na przykładzie pomidorów oaz kalafiorów. Uzyskane wyniki były zbieżne z wynikami zaprezentowanymi w niniejszym opracowaniu. Jordan oraz VanSickl (1995), wykorzystując dane empiryczne dotyczące poziomu cen pomidorów dokonali analizy powiązań pomiędzy rynkami na Florydzie oraz w Meksyku. Wykazali oni, że pomiędzy tymi rynkami istnieje integracja przestrzenna. Badacze ci zauważyli jednak, że przepływ informacji cenowych pomiędzy badanymi przez nich rynkami hurtowymi jest asymetryczny. Należy wskazać, że ze względu na brak opracowań dotyczących integracji przestrzennej rynków hurtowych w sektorze ogrodniczym, opracowanie stanowi uzupełnienie luki poruszanego obszaru.

\section{Literatura}

Borkowski, B., Krawiec, M. (2009). Ryzyko cenowe na rynku surowców rolnych. W: Zarządzanie ryzykiem cenowym a możliwości stabilizowania dochodów producentów rolnych - aspekty poznawcze i aplikacyjne (Price risk in the market of agricultural commodities. In: Price risk management and the possibilities of stabilizing the income of agricultural producers - cognitive and application aspects). Raport Programu Wieloletniego. Nr 148, 47-82.

Faminow, M.D., Benson, L.B. (1990). Integration of Spatial Markets. American Journal of Agriculture Economics, 72(1), 49-62.

Ghos, M. (2000). Cointegration tests and spatial integration of rice markets in India. Indian Journal of Agricultural Economics, 55(4), 616-623.

Goletti, F., Ahmed, R., Farid, N. (1995). Structural determinant of market integration: The case study of rice in Bangladesh. The Development Economics, 32(2), 185-202.

Gołębiewski, J., Sobczak, W. (2017). Rynki hurtowe owoców i warzyw (Wholesale markets for fruit and vegetables). Wydawnictwo SGGW.

Goodwin, B.K., Schroeder, T.C. (1991). Cointegration tests and spatial price linkages in regional cattle markets. American Journal of Agricultural Economics, 73(2), 452-464.

Granger, C.W.J. (1969). Investigating Causal Relations by Econometric Models and Cross-spectral Methods. Econometrica, 37(3), 424-438. 
Jordan, K.H., VanSickle, J.J. (1995). Integration and Behavior in the U.S. Winter Market for Fresh Tomatoes. Journal of Agricultural and Applied Economics, 27, 127-137.

Kusideł, E. (2000). Modele wektorowo-autoregresyjne VAR. Metodologia i zastosowanie. W: Suchecki B. (red.), Dane panelowe i modelowanie wielowymiarowe w badaniach ekonomicznych (Vector-autoregressive VAR models. Methodology and application. In: Panel data and multidimensional modeling in economic research). Tom. 3, Wyd. Absolwent.

Maddala, G.S. (2008). Ekonometria, Econometrics, Wyd. PWN.

Mauyo, L. W., Okalebo, J. R., Kirkby, R. A., Buruchara, R., Ugen, M., Mengist, C.T., Anjichi, V.E., Musebe, R.O. (2007). Technical efficiency and regional market integration of cross-border bean marketing in western Kenya and eastern Uganda. African Journal of Business Management, 77-84.

Negassa, A., Meyers, R., Gabre-Maldhin, E. (2004). Analyzing the grain market efficiency in developing countries: Review of existing methods and extensions to the parity bound model, Market trade and institutions division, Discussion paper no. 66, International Food Policy Research Institute, Washington DC $2004,5-8$.

Rembeza, J, Chotkowski, J. (2006). Powiązanie cen produktów rolnych pomiędzy rynkiem polskim a rynkami UE (Price linkages between Polish and EU agricultural markets). Problemy Rolnictwa Światowego, 14, 198-204.

Santeramo, F.G. (2015). Price Transmission in the European Tomatoes and Cauliflowers Sectors. Agribusiness, 31(3), 399-413.

Serra, T., Gil, J.M., Goodwin, B.K. (2006). Local polynomial fitting and spatial price relationships: price transmission in EU pork markets. European Review of Agricultural Economics, 33(3), 415-436.

Sexton, R.J., Kling, C.L., Carman, H.F. (1991). Market Integration, Efficiency of Arbitrage and Imperfect Competition: Methodology and Application to US Celery. The American Journal of Agricultural Economics, $73,568-580$.

Sims, C. (1980). Macroeconomics and Reality. Econometrica, 48, 1-48.

Stachowiak, B. (2013). Wykorzystanie ekonomii przestrzennej w procesach rozwoju gospodarczego (Implementation of spatial economics in the economics development proces). Zeszyty Naukowe Uniwersytetu Przyrodniczo-Humanistycznego w Siedlcach, 97, 209-217.

Do cytowania / For citation:

Sobczak W., Zbyrowski R. (2018). Integracja przestrzenna rynków hurtowych zastosowanie dla rynku fasoli szparagowej. Problemy Rolnictwa Światowego, 18(4), 426-436; DOI: 10.22630/PRS.2018.18.4.131

Sobczak W., Zbyrowski R. (2018). Spatial Integration of Wholesale Markets - Application for the Green Bean Market (in Polish). Problems of World Agriculture, 18(4), 426-436;

DOI: 10.22630/PRS.2018.18.4.131 